moderate politicians who speak of "Dominion status in 1956". 'The College is a fully autonomous institution, and so far there have been few attempts, save by the less responsible organs of the popular press, to interfere with this autonomy. Nevertheless, until the College and its standards are firmly established the danger of outside political pressure will remain, and will impose an added strain on those responsible for the well-being of an institution on which the future of Nigeria itself depends so greatly.

\section{INTERNATIONAL FEDERATION FOR DOCUMENTATION}

\section{CONFERENCE IN COPENHAGEN}

$\mathrm{T}$

HE International Federation for Documentation held one of its 'restricted' conferences in Copenhagen during September 28-October 4, which was attended by representatives of some sixteen countries. These conferences consist of a number of meetings of the council and of the active specialist committees of the Federation. Among the committees which met on this occasion were those on universal classification, mechanical selection, technical means of documentation, abstracting, training, and information services. Meetings were also held between members of the staff of the United Nations Educational, Scientific and Cultural Organization and representatives of the council of the International Federation for Documentation, the International Federation of Library Associations and other international bodies concerned with documentation, archives and librarianship. As a step towards closer collaboration, it was agreed that both the International Federation for Documentation and the International Federation of Library Associations should become members of the other's organization and that the next conferences of the two bodies should take place simultaneously in Vienna in 1953. It was also agreed with the representatives of Unesco that a joint consultation committee of international non-governmental organizations in the field of librarianship, documentation and archives be established, and that this committee should arrange the next world conference on these subjects to be held in 1954 or 1955 .

One of the main items discussed by the council of the Federation was the report of its committee on reorganization, which was set up at the end of the conference held in Rome in 1951. This report, which was accepted after minor modification, restated the aims of the Federation in terms suitable for the present; in particular, it made clear that such a body should restrict its activities to those which are truly international in character, leaving studies of a more general nature to its national constituent bodies. Similarly, it was agreed that international technical studies should not necessarily be carried out by the general secretariat but allocated to appropriate national members who would undertake them for the benefit of the Federation as a whole. It also recommended that international specialist bodies should be accepted as members of the Federation in addition to the national co-operating bodies (Aslib in the case of Great Britain). It was recognized that, with the increased amount of research undertaken, especially in the pure and applied sciences, and the consequent volume of publication, special problems of documentation are arising in many scientific and technical fields. As a result, a number of specialist international bodies have already been established, such as the International Council on Building Documentation which was meeting at Copenhagen at the same time as the International Federation for Documentation. The Federation felt itself to be in a position to give advice to international bodies for specialized topics, such as the various international scientific unions, on documentary aspects of their work, and decided to create facilities for such bodies to join the Federation and participate fully in its work.

Among the technical matters agreed as appropriate to the programme of the Federation for 1953, priority was given to the proposals for a guide to centres for microfilm and photocopying services, and centres for international loans and translation services; the production of manuals for instruction in documentation; a directory of the effective members of the Federation, with a description of their activities ; a study of auxiliary publications, including 'unpublished' reports of scientific work; a study of costing and economics in the preparation and sale of photocopies; and a manual of documentary reproduction.

This conference, with its wide scope of technical interest, demonstrated clearly the need for improved services of documentation and information as well as the interest of scientific and technological workers in problems resulting from the mounting pressure of publication. Although a number of international organizations are operative in this and neighbouring fields, the International Federation of Documentation, in encouraging co-operation with other bodies while at the same time improving its own organization and procedures, is showing real leadership and finding a useful continuing function.

\section{ADVISORY COMMITTEE ON ARID ZONE RESEARCH}

\section{MEETING IN LONDON}

$\mathrm{T}$ HE Advisory Cornmittee on Arid Zone Research set up by the United Nations Educational, Scientific and Cultural Organization held its fourth meeting in the Royal Society's rooms, Burlington House, London, during September 29-October 1. Following its former policy, the Committee's recommendations were concerned to a large extent with the dissemination and exchange of information by means of reports and symposia. Reports have already been obtained and circulated on arid zone hydrology, on plant ecology, on the climatic history of arid regions and on the utilization of salt water. A successful symposium on arid zone hydrology organized jointly by Unesco and the Turkish Government was held in Ankara last April. The Committee recommended that qualified experts be commissioned to prepare reports reviewing research on energy sources, including wind and solar energy and their utilization in arid and semi-arid regions, and also on the general characteristics of arid zone soils and their modification. It also recommended that a survey of current research in the field of arid zone plant ecology be prepared. The symposium planned to be held in 1953 will deal with this field of plant ecology in arid regions, and the Committee considered its programme and plans. 
for holding it in a Latin-Ameriean country in the autumn.

Plans were also discussed for the production of a handbook to assist those confronted with the task of collecting basic data required before schemes can be prepared to develop an arid or semi-arid area. Such a handbook would aim at serving two purposes. It would first direct the attention of persons concerned with organizing development to the various and interrelated fields in which data are needed before satisfactory plans for such development can be made. Secondly, it should give information as to the best methods of collecting and presenting basic data in a form that supplies the information needed for their practical application.

A scheme is now in operation in which certain institutions carrying out research relating to arid zone problems may be designated as suitable for the exchange of personnel and information and for the reception of visiting scientific workers. A number of applications for designation under this scheme were considered by the Committee, which recommended that the following institutions be added to those already designated at earlier meetings :

Commonwealth Research Station (Murray Irrigation Areas), Merbein, Victoria.

Division of Plant Industry (C.S.I.R.O.), Black Mountain, Canberra.

Irrigation Research Station (C.S.I.R.o.), Private Mail Bag, Griffith 58, New South Wales.

Katherine Research Station. Katherine, Northern Territory.

National Field Station, "Gilruth Plains", Cunnamulla, Queensland.

Information on Regional Pastoral Laboratory, Denilquim, Box 26, P.O., New South Wales.

Laboratorium voor Grondmechanica, Oostplantsoen 25, Delft.

Waterloopkundig Laboratorium (Hydraulic Laboratory), Raam 61 , Delft.

Amarillo Conservation Experiment Station, Box 2169, Amarillo, Texas. Department of Geology, University of Southern California, 3518 University Avenue, Los Angeles 7, California.

Inter-Mountain Forest and Range Experiment Station, U.S. Forest Service Building, Ogden, Utah

Information on Reclamation Engineering Centre, Denver, Colorado.

South-western Forest and Range Experiment Station, Tucson, Arizona. University of Arizona, Tucson, Arizona.

University of California Citrus Experiment Station, Riverside,

Particulars of these institutions and of the facilities available at each can be obtained from Unesco (19 Avenue Kléber, Paris $16 \mathrm{e}$ ). The Committee also recommended that member States be reminded of this scheme and be supplied with a full list of institutions at present associated under it.

As a result of an earlier recommendation by the Committee, a survey has been conducted by Unesco of institutions engaged in research on arid zone problems, and the Committee recommended that the information thus collected should be made use of to compile a directory of institutions engaged in arid zone research.

On the research side the Committee recommended that assistance be given to the following projects. (1) A project proposed by the Institut Français d'Afrique Noire to study the effects on plant cover of natural factors, mainly climatic, and of human intervention such as grazing, trampling and wood cutting. Data on this subject are much needed, especially since they bear on the deterioration of natural pastures. (2) A project proposed by Dr. F. W. Went, of the Earhart Plant Research Laboratory, California Institute of Technology, to study the role of dew in plant growth in arid regions. (3) A project proposed by Dr. K. Smidt Nielsen, of Duke University, North Carolina, to study the physiology of the camel and of other desert mammals. This work would extend that already carried out by
Dr. and Mrs. Smidt Nielsen on the physiological mechanisms which enable certain desert rodents to live on dry food without drinking water. (4) A project proposed by Prof. L. Picard, Geological Institute, Jerusalem, Israel, to investigate the climatic changes that have taken place during the Quaternary in the arid and semi-arid region of the south-east Mediterranean, initially by means of a study of the peat deposits of northern Galilee.

\section{EUROPEAN COUNCIL FOR NUCLEAR RESEARCH}

\section{SESSION IN AMSTERDAM}

THE third session of the European Council for Nuclear Research was presided over by Prof. P. Scherrer when it met at the Academy of Sciences, Amsterdam, during October 4-6. The main work before the Council was to consider the offers which had been made by various member States for the site of the proposed laboratory, to hear reports of progress made by its four study groups, and to consider a report from its secretary-general, Prof. E. Amaldi, on the organization and financial implications of future European co-operation in nuclear research. Last June the Council sponsored a scientific conference at Copenhagen to promote a broad exchange of views upon the problems of nuclear research which could be most profitably dealt with by international co-operation. As a result of this conference, it has been decided that the study of mesons and the other new particles which have recently been found in the cosmic rays should be developed by international co-operation, and by the construction of high-energy machines in a suitable centre so that these particles might be created artificially. Four working-groups were formed by the Council to carry out the following respective tasks : the first to design a $600-\mathrm{MeV}$. synchrocyclotron; the second to design a proton synchrotron of not less than $10 \mathrm{GeV}$. $\left(10^{10} \Theta \mathrm{V}.\right)$ energy ; the third to study theoretical and experimental developments having a. bearing on the aims of the Council and to promote other forms of European co-operation in nuclear physics; and the fourth to explore the organization and structure of a suitable laboratory.

Rapid progress with the design study of the $600-\mathrm{MeV}$. synchrocyclotron was reported by Prof. C. J. Bakker. The main features of the magnet design have been settled, and also the layout of the vacuum chamber and radio-frequency system. At one stage it had been intended to use a rotary condenser to provide the necessary radio-frequency tuning, but as a result of a recent visit to the Radiation Laboratory of the University of California, the use of a vibratingreed method of tuning is now being studied. The general design has advanced to the stage where it is necessary to start considering the manufacture of the various components.

Prof. O. Dahl reported that, since the last Council meeting in Copenhagen in June, an event of considerable scientific interest has occurred which has profoundly affected the work of the Proton Synchrotron Group. Drs. E. D. Courant, M. S. Livingston and H. S. Snyder, of the Brookhaven National Laboratory, have proposed a new focusing principle applicable to a high-energy proton synchrotron. 